\title{
Comment and Reply on "Late Triassic paleogeography of the southern Cordillera: The problem of a source for voluminous volcanic detritus in the Chinle Formation of the Colorado Plateau reglion"
}

\section{COMMENT}

Richard V. Wyman, University of Nevada, Las Vegas, Nevada 89154

I disagree with the basic premise of the paper by Stewart et al. (1986) and the consequent speculative interpretation of the source area for Chinle rocks in the Colorado Plateau.

The basic assumption, that Chinle rocks are older than the igneous rocks of the source area volcanism, is based upon an improper comparison. Stewart et al. compared a group of calculated radiometric dates in southern Arizona with a relative age based on paleontologic geochronology lacking radiometric verification. They ignored the considerable work that was done about 20 years ago on the age of the Chinle, especially with regard to the basal Shinarump Conglomerate. A comparison based on these radiometric dates leads to a very different conclusion.

Chinle. Is the Chinle Formation of Carnian age, as Stewart et al. (1986) stated? The ages of the boundaries of the Carnian (225 to $230 \mathrm{Ma}$ ) as represented on the Decade of North Annerican Geology geologic time scale (Palmer, 1983) were determined about $3220 \mathrm{~km}$ (2000 mi) away in British Columbia (Armstrong, 1982). The only evidence linking the Chinle Formation to this interval is based on pollen and spores. Stewart et al. (1986) reported K-Ar ages on four cobbles, but no other radiometric ages on Chinle rocks. They never mentioned the Shinarump, the basal member of the Chinle, about which much has been written. The direction of stream flows from the south were largely determined from channels in this basal member.

The age of the Chinle has been a matter of considerable study. Young (1964) and Miller and Kulp (1963) discussed the radiometric age of this formation and the discrepancies between methods, and they concluded that ${ }^{235} \mathrm{U} /{ }^{207} \mathrm{~Pb}$ gives the most reliable minimum age. Five samples from the Shinarump near Cameron, Arizona, averaged $175 \mathrm{Ma}$. Seven samples from Lisbon Valley, Utah, averaged $150 \mathrm{Ma}$. Young (1964) concluded, on the basis of radiometric age determination, that the Chinle is younger than $180 \mathrm{Ma}$. This 'would place it in Middle Jurassic rather than Carnian.

Mesozoi: Volcanic Rocks. In view of the ages shown by Stewart et al. (1986), there are enough dates of igneous rocks in southern Arizona between 150 and $180 \mathrm{Ma}$ that correspond to the radiometric ages of the Chinle, and these rocks could have supplied the volcanic tuffs of the Chinle.

The problem, therefore, is the relative age of the Chinle, rather than the mystery of the disappearing source volcanism.

\section{REPLY}

John H. Stewart, U.S. Geological Survey, Menlo Park, California 94025

Thomas H. Alderson, University of Pittsburgh, Pittsburgh, Pennsylvania 15620

Gordon B. Haxel, U.S. Geological Survey, Flagstaff, Arizona 86001

Leon T. Silver, Califormia Institute of Technology, Pasadena, California 911.25

James E. Wright, Stanford University, Stanford, California 94305

On page $\$ 69$ of our article (Stewart et al., 1986) we emphasized the critical dependence of our ideas upon the validity of the isotopic and paleontologic geochronology, and on the calibration between the two methods. Wyman also emphasizes this same point but introduces other information-rlamely, isotopic dates on uranium ores in the Chinle Formation. He indicates, citing the work of Miller and Kulp (1963), that the average date for uranium ores in the Chinle Formation in the Cameron area, Arizona, is $175 \mathrm{Ma}$ and in Lisbon Valley, Utah, is $150 \mathrm{Ma}$. These averages, however, seem meaningless because they incorporate individual dates that range: from 101 to $218 \mathrm{Ma}$ at Cameron, and from 95 to $207 \mathrm{Ma}$ 
at Lisbon Valley. In any case, recent data (not cited by Wyman) gives a concordant $\mathrm{U}-\mathrm{Pb}$ age of $206 \pm 1 \mathrm{Ma}$ for uranium ores from the Chinle Formation in Lisbon Valley (Ludwig et al., 1986).

These isotopic ages on uranium ores, as Wyman indicates, are minimum ages for deposition of the lower part of the Chinle Formation, and surely cannot be used, as Wyman does, to indicate a Middle Jurassic age for the Chinle. Abundant paleontologic information indicates a Late Triassic age for the lower part of the Chinle, perhaps best defined by information on pollen and spores that we cited in our article, but also based on vertebrates, plants, and other fossils (see summary by Stewart et al., 1972; Ash, 1980).

As reported in our article, the oldest volcanic rocks in south-central Arizona and northern Sonora are $189 \pm 10 \mathrm{Ma}$ and most are younger than $190 \mathrm{Ma}$. Preliminary interpretation of isotopic $\mathrm{U}-\mathrm{Pb}$ ages published after our article (Riggs et al., 1986; N. R. Riggs, 1987, oral commun.) indicates that the age of the Mount Wrightson Formation, the oldest Mesozoic volcanic rocks in part of southeastern Arizona, is $206 \pm 5 \mathrm{Ma}$. Thus, the $\mathrm{U}-\mathrm{Pb}$ ages obtained by Wright et al. (1981) and those obtained by Riggs et al. (1986) are similar. The approximate numerical age of the paleontologically dated (Carnian) part of the Chinle that contains volcanic detritus is 225 to $230 \mathrm{Ma}$ (Palmer, 1983). Thus a minimum of about $20 \mathrm{~m}$.y., and more likely $35 \mathrm{~m} . y$., appears to separate the volcanic part of the Chinle Formation and the oldest Mesozoic volcanic rocks in southern Arizona.

The calibration of the paleontologic ages with isotopic ages is continually evolving, but we feel that the difference in ages of $20 \mathrm{~m}$.y., and for most rocks $35 \mathrm{~m}$.y., is sufficient to indicate a real difference between the volcanic part of the Chinle Formation and the volcanic rocks in southern Arizona. As independent supporting evidence, we noted that eolian sandstone units occur in the volcanic sequences in southern Arizona and that these units lithologically resemble the eolian Navajo Sandstone (Bilodeau and Keith, 1986), a post-Chinle unit of the Colorado Plateau region.

\section{COMBINED REFERENCES CITED}

Armstrong, R.L., 1982, Late Triassic-Early Jurassic time scale calibration in British Columbia, Canada, in Odin, G.S., ed., Numerical dating in stratigraphy: New York, John Wiley \& Sons, p. 509-513.

Ash, S.R., 1980, Upper Triassic floral zones of North America, in Dilcher, D.L., and Taylor, T.N., eds., Biostratigraphy of fossil plants: Stroudsburg, Pennsylvania, Dowden, Hutchinson and Ross, Inc., p. 153-170.

Bilodeau, W.L., and Keith, S.B., 1986, Lower Jurassic Navajo-Aztec-equivalent sandstones in southern Arizona and their paleogeographic significance: American Association of Petroleum Geologists Bulletin, v. 70, p. 690-701.

Ludwig, K.R., Rasmussen, J.D., and Simmons, K.R., 1986, Age of uranium ores in collapse-breccia pipes in the Grand Canyon area, northern Arizona: Geological Society of America Abstracts with Programs, v. 18, p. 392.

Miller, D.S., and Kulp, J.L., 1963, Isotopic evidence on the origin of the Colorado Plateau uranium ores: Geological Society of America Bulletin, v. 74, p. $609-630$.

Palmer, A.R., 1983, The Decade of North American Geology 1983 geologic time scale: Geology, v. 11, p. 503-504.

Riggs, Nancy, Mattinson, J.M., and Busby-Spera, Cathy, 1986, U-Pb ages of the Mount Wrightson Formation, southern Arizona, and possible correlation with the Navajo Sandstone: EOS (American Geophysical Union Transactions), v. 67, p. 1249.

Stewart, J.H., Poole, F.G., and Wilson, R.F., 1972, Stratigraphy and origin of the Chinle Formation and related Upper Triassic strata in the Colorado Plateau region with a section on Sedimentary petrology by R.A. Cadigan and on Conglomerate studies by William Thordarson, H.F. Albee, and J.H. Stewart: U.S. Geological Survey Professional Paper 690, 336 p.

Stewart, John H., Anderson, T.H., Haxel, G.B., Silver, L.T., and Wright, James E., 1986, Late Triassic paleogeography of the southern Cordillera: The problem of a source for voluminous volcanic detritus in the Chinle Formation of the Colorado Plateau region: Geology, v. 14, p. 567-570.

Wright, J.E., Haxel, G.B., and May, D.J., 1981, Early Jurassic uranium-lead isotopic ages for Mesozoic supracrustal sequences, Papago Indian Reservation, southern Arizona: Geological Society of America Abstracts with Programs, v. 13, p. 115.

Young, Robert G., 1964, Distribution of uranium deposits in the White CanyonMonument Valley districts, Utah-Arizona: Economic Geology, v. 59, p. $850-873$.

\section{Comment and Reply on "Strike-slip faulting and block rotation in the Lake Mead fault system"}

\section{COMMENT}

Peter L. Guth, Eugene I. Smith, Department of Geoscience, University of Nevada, Las Vegas, Nevada 89154

The discussion of Ron et al. (1986) on the Lake Mead fault system sets up a false dichotomy in considering two independent mechanisms for crustal extension (strike-slip faults vs. normal faults). They seriously undermine their argument by ignoring reports of detachment faulting in the region (Choukroune and Smith, 1985) and the likelihood that both normal and strike-slip faults represent upper-plate adjustments of regional detachment structures.

Detachment faulting dominates extension in the Basin and Range province; normal and strike-slip faults play subordinate roles (Wernicke, 1981). The mechanism proposed by Anderson (1973, Figs. 3 and 6) elegantly integrates normal and strike-slip faults into regional extension, explains the abrupt termination of strike-slip faults, and has been widely applied (e.g., Guth, 1981; Wernicke et al., 1982). Although Anderson's work predated the detachment model, it fits well with the extensional allochthon concept (Wernicke, 1981). Anderson (1973) constructed threedimensional models that explain mapped field relations, but Ron et al. (1986) presented only a cartoon sketch.

On the basis of paleomagnetic data, rotation about a vertical axis was reported in the Desert Range $90 \mathrm{~km}$ northwest of Lake Mead (Gillett and
Van Alstine, 1979, 1982). Clockwise rotation of $44^{\circ}$ north of the rightlateral Las Vegas Valley shear zone was clearly associated with up to $60^{\circ}$ of tilting on normal faults. Detailed structural mapping in the Desert Range and vicinity (Guth, unpub.) suggests that the upper plate of the Sheep Range detachment broke into blocks (kilometres wide and tens of kilometres long) that translated, rotated, and tilted.

We question the validity of the "volcano test" (Ron et al., 1986); it creates a simplistic dichotomy. Ron et al. (1986) proposed two alternatives for tilting of lava flows: current attitudes are original, or all tilt is tectonic. They ignored a more likely option, that initial dips of the lava flows were modified by tilting. Although their Figure 5a shows less scatter than Figure $5 \mathrm{~b}$, the test cannot prove a lack of significant structural tilting. The "volcano test" is not comparable to a "fold test" in which an initial horizontal orientation of the folded bed can be assumed, because initial attitudes of individual volcanic flows were not determined.

Their analysis concerned only the Hamblin-Cleopatra volcano and not the entire Lake Mead region. Their five localities (in their Fig. 3, the 22 sites plot at only five locations) occur in a restricted area within strands of the Lake Mead fault system. Ron et al. attributed tilting of Tertiary beds north of their study area to folding. They ignored the many faults mapped in that area (Bohannon, 1983) and the conclusion that "from about 12 to 10.5 or possibly $10 \mathrm{~m} . y$. ago, sedimentation patterns were severely disrupted by an episode of block faulting" (Bohannon, 1984, p. 66). Additionally, south of Lake Mead, Anderson $(1971,1978)$ demonstrated 